\title{
Groundwater Modeling and Governance: Contesting and Building (Sub)Surface Worlds in Colorado's Northern San Juan Basin
}

\author{
ADRIANNE C. KROEPSCH \\ COLORADO SCHOOL OF MINES
}

\begin{abstract}
As groundwater use has surged globally and computing power has grown, groundwater modeling has become a regular feature of subsurface-oriented governance. Our improved ability to "see" underground with models has not, however, generated epistemic consensus on the inner workings of subsurface systems. Here, I ask how and why that is the case. I pursue this line of inquiry in the context of groundwater governance in the American West. Specifically, I trace a decade of groundwater modeling at the heart of a protracted and legally influential groundwater dispute in the state of Colorado to show how models served as mathematical spaces for competing subsurface stakeholders to test and contest opposing visions of groundwater flows, rights, and responsibilities. Drawing from the Science \& Technology Studies literature on global climate modeling, I argue that groundwater models are more than simulations of subsurface systems; they are tools of "world building" that embed, enact, and also circumscribe subsurface politics.
\end{abstract}

\section{Keywords}

groundwater; modeling; STS of the subsurface; hydrogeology; American West

\section{Introduction: Seeing Underground}

In the summer of 1890, John Wesley Powell, the director of the United States Geological Survey and famed explorer-scientist, found himself in a fight with a lawmaker over an aquifer. Senator Gideon C. Moody had steered a congressional hearing about Powell's surveys of water resources in the American West to the topic of groundwater supplies in his home state of South Dakota. Irritated by Powell's desire to limit agriculture in the country's arid interior, Moody argued for the opposite approach. He wanted the federal government to speed up farming in the Dakotas, and he wanted Powell to help by sinking experimental wells throughout the region to reveal the limitless reservoirs of groundwater he was certain could be found there. When Powell explained

Adrianne C. Kroepsch, Email: akroepsch@mines.edu

Copyright (C) 2018 (Adrianne C. Kroepsch). Licensed under the Creative Commons Attribution Non-commercial No Derivatives (by-nc-nd). Available at estsjournal.org. 
to Moody that he had already mapped the geologic formations in question and cautioned him about the perils of groundwater overdrafting, the senator took aim. "Of course I have got a great respect for scientifically educated gentlemen, and I am always very much interested in their researches and all that, but you cannot satisfy an ordinary man by any theoretical scheme or by any science," Moody retorted. "To use a common expression of the average miner, 'One man can see in the ground no farther than another, unless there is a hole in it"' (USGPO 1891, 73).

The senator did not trust Powell's geologic mapping or his interpretations of underground space. Moody wanted more holes in the ground to peer into directly. More than a hundred years later, he has gotten them. In the American West and globally, the subsurface is now riddled with man-made holes-holes for water wells, oil and natural gas wells, mines, tunnels, and the likes. Geophysical methods such as seismic mapping even allow people to peer into the earth without holes at all, and computer-based modeling has made it possible to interpolate among holes to reveal subsurface dynamics at broader scales. In ways that Senator Moody could not have predicted in 1890, scientists do now enjoy the ability to "see in the ground farther" than the rest of us. That more expansive underground view has not, however, generated epistemic consensus about the inner workings of subsurface systems. Despite the proliferation of subsurface windows over the past hundred-plus years, scientists, policymakers, industries, and the "ordinary man" still frequently disagree about what is, or is not, going on underground. Subsurface space persists as a zone of contention on topics from groundwater use, to hazardous waste disposal, to mining and oil and gas extraction, and more (Birkenholtz 2008; Birkenholtz 2015; Bolin et al. 2008; Budds 2009; de Rijke et al. 2016; Holifield 2009).

That puzzle inspires this paper. Here, I ask how and why it is that our improved ability to "see" underground has not generated epistemic consensus about subterranean space. With all of the boreholes and tools available in the twenty-first century, why is it still so easy to disagree about subsurface happenings? Following Moody and Powell, I pursue this line of inquiry in the context of groundwater governance in the American West. More specifically, I explore the mode of subsurface representation that is most common in today's policy debates over underground dynamics: computer-based modeling. Computer-based modeling of the subsurface is an obvious area for STS inquiry, and yet STS-inspired scholarship on the production of subsurface knowledge has thus far largely overlooked the topic. Rather, STS studies that focus on technologies' roles in knowing underground systems have been grounded primarily in Senator Moody's day, with a special focus on the tools used to find pay dirt in that era's oil fields (Bowker 1994; Frehner 2011). In this paper, I shift the conversation to a contemporary technology for "seeing" underground-groundwater modeling-as well as to the contemporary policymaking arenas where groundwater models find frequent use.

In the words of Kim Fortun, "Environmental politics are also data politics" $(2016,5)$. When it comes to subsurface data politics, models play an especially formative role. I argue that groundwater models are best understood not as mere simulators of subsurface systems, but as tools of "world building" that actively embed, enact, and also circumscribe subsurface politics (Edwards 2001, 62). Here I trace a decade of groundwater modeling at the heart of a protracted and legally influential groundwater dispute in the state of Colorado to show how models served 
as mathematical spaces for competing subsurface stakeholders to test and contest opposing visions of groundwater flows, rights, and responsibilities. At stake in these model-based debates were scientific questions of whether groundwater withdrawn during natural gas extraction technically belonged to surface water rights holders already strapped for flows in an arid region; in other words, whether surface and subsurface water sources were hydraulically connected to one another. A close look at this epistemic dispute also reveals important technopolitical stakes. Regulators' reliance on models delimited who spoke for the subsurface and buoyed the privatization of hydrologic knowledge in ways that reinforced mistrust among stakeholders and generated further legal battles.

This analysis proceeds in four parts. First, I describe the contours of the Colorado groundwater case. Second, I turn to the STS literature on global climate modeling for insights on how knowledge and politics are co-produced in the modeling of hard-to-know systems and spaces. I also provide a brief overview of groundwater governance and model building. Third, I analyze models' roles in the Colorado groundwater case and, fourth, I conclude with a discussion of broader implications for subsurface stewardship.

\section{A Subsurface Starting Point}

This analysis is partly inspired by personal experience. In the summer of 2010, as a graduate student in hydrology, I found myself collecting water samples in a region of southwestern Colorado known geologically as the Northern San Juan Basin (NSJB). Since roughly the 1990s, the basin's natural-gas-rich Fruitland Formation coal layer has been the target of intensive coalbed methane (CBM) development. Groundwater features centrally in the extraction of natural gas from the Fruitland coals because, like most methane-rich coal formations, the Fruitland Formation is also saturated with water-water that must be removed before the formation will surrender lucrative volumes of natural gas. In industry parlance, the groundwater extracted in the process of producing oil or gas is called "produced water." By the time I arrived in the NSJB, the region's CBM well count was over 1,000 and growing, and the CBM industry was withdrawing approximately 3,000 acre-feet ${ }^{2}$ of produced water from the Fruitland Formation per year (Papadopulos 2006). Too salty to use, this produced water was being trucked away to deep well disposal sites.

The two federal public lands agencies in the area--the Bureau of Land Management and the US Forest Service, collectively known at the time as the San Juan Public Lands Center (SJPLC)—had commissioned the study to which I was contributing because these produced water withdrawals had them worried about something. They were concerned that the CBM industry's dewatering of the Fruitland Formation might inadvertently be intercepting surface flows in local rivers (SJPLC 2006). The Fruitland Formation sat a thousand or more feet below ground in the reaches of the basin where operators were drilling CBM wells. But the Fruitland

- The acre-foot is the hydrologic unit of choice in the Western United States; it is the volume required to flood a one-acre field to a foot in depth. 3,000 acre-feet $=840$ million gallons. 
met the surface (or "outcropped") just a few miles away from the drilling activity. Several major tributaries to the San Juan River flowed across the Fruitland Formation where it was exposed at its outcrop. The big unknown was whether the Fruitland Formation typically contributed groundwater to those five rivers where they crossed it, and whether in turn the CBM industry's produced water withdrawals might be intercepting those flows (SJPLC, 2006). If the CBM industry was indeed intercepting groundwater destined for local rivers, the implications were serious. That water had already been claimed by senior surface water rights holders in the area, mostly ranchers and farmers reliant on small and over-appropriated local streams. Anecdotal evidence of drying springs near the Fruitland Outcrop suggested the CBM industry's dewatering of the Fruitland might be having a wider hydrologic impact, but nobody knew for sure.

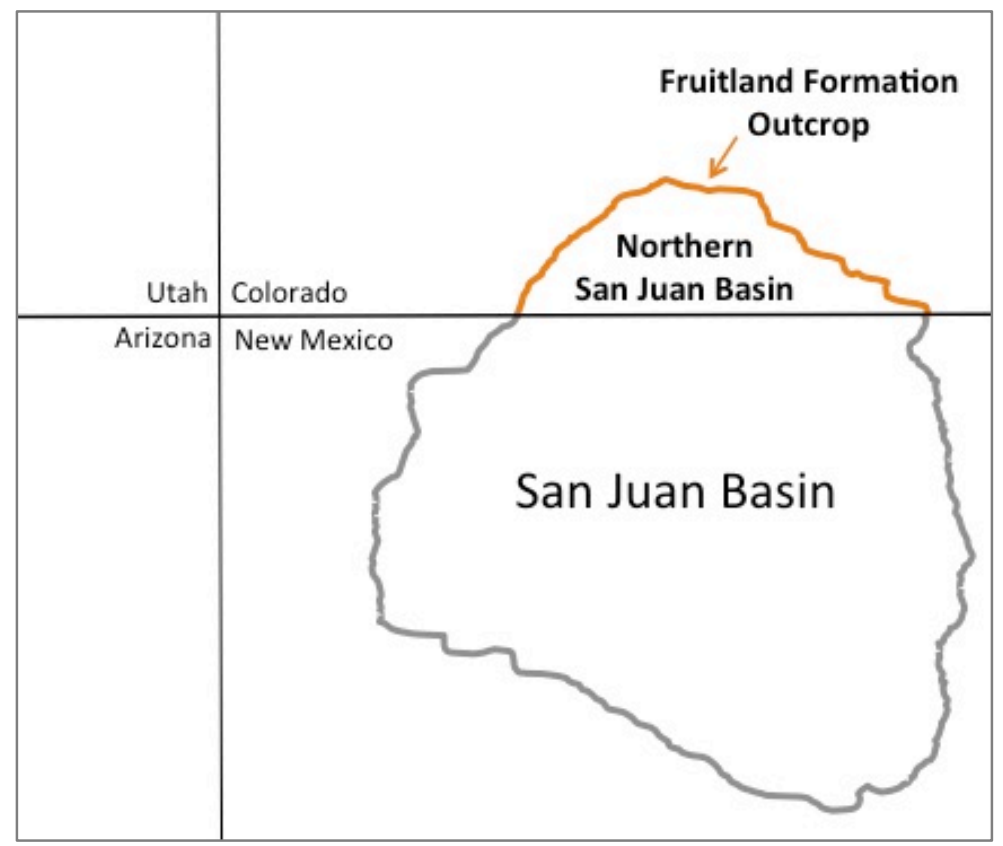

Figure 1. Map of the Northern San Juan Basin in southwestern Colorado with the Fruitland Formation Outcrop highlighted in orange.

The scientific question afoot in the NSJB could therefore be summarized in three parts: (1) whether the Fruitland Formation is hydraulically interconnected within itself, (2) whether the Fruitland Formation is hydraulically connected to rivers at its northern outcrop, and (3) whether the CBM industry's dewatering of the Fruitland Formation was intercepting groundwater that usually fed those rivers. SJPLC officials had been grappling with these unknowns because each time the CBM industry decided to drill more wells on federal public lands in the basin, it was the SJPLC's job to generate an Environmental Impact Statement (EIS) and make a decision about how many more wells it would permit. Judging by the vast scientific literature that had been 
produced on the NSJB by the 2000s, one might have assumed this would be a straightforward call. After all, the NSJB was one of the most carefully studied CBM basins in the world by then (Snyder \& Fabryka-Martin 2007). And yet intense uncertainty and disagreement about the inner workings of the Fruitland Formation and the hydrologic impacts of CBM extraction persisted among resource managers, CBM industry members, and local ranchers and farmers (Klahn 2010).

Groundwater modeling had not resolved this contention. By the time I was collecting water samples in the NSJB in 2010, a series of exhaustive groundwater modeling efforts had been underway for more than a decade with the intention of demystifying Fruitland Formation dynamics. In the process, federal and state natural resource managers had been handed no fewer than five groundwater models designed to decipher regional groundwater flow and groundwater-surface water interactions in the basin. But despite these modeling efforts, there I was in the summer of 2010, knee deep in two of the rivers in question on a twice-weekly basis trying to help resolve lingering uncertainties by collecting empirical evidence. The hydrologic data were intended to characterize surface-groundwater interactions so that they could be monitored for change over time (Williams et al. 2010), as drilling continued a few miles away-and as subsurface unknowns, data disputes, and mistrust persisted.

On an individual level, my fieldwork left me wondering about the implications of the subsurface's inscrutability for natural resources management. More to the point, my NSJB research raised the question of whether, given peoples' need to "see it to believe it" when it comes to environmental phenomena (Hansen \& Machin 2013), it is possible to develop shared understandings of largely invisible subsurface systems, especially when over-appropriated and/or profitable subsurface resources are at stake. The question is not only mine, of course. Major common pool resource management theories hold that an essential starting point for groundwater governance is developing a shared understanding of the relevant groundwater system among its users (Ostrom 1990; 1964). And yet, in the NSJB case, the chief method for discerning basin-scale groundwater dynamics—computer-based modeling—had not generated a shared understanding of the underground.

Eager for more clarity, I scrutinized what I could find about groundwater disputes in a variety of circumstances-in other states, other countries, over different sorts of groundwater uses, and with varying numbers of models involved. Some of these epistemic contests appeared to hinge upon the politics of whose knowledge and data made it into governance processes (Birkenholtz 2008; deRijke et al. 2016), often with groundwater models as gatekeepers (Budds 2009). Others seemed to center around cases of adversary modeling, in which opposing stakeholders brought conflicting models to groundwater disputes in order to make the case for particular legal or regulatory outcomes (Bolin et al. 2008; Hollifield 2009). Taken together, these examples suggested, in the words of deRijke et al. (2016), that people make the underground legible "through an ontological politics that renders certain knowledges, engagements, and worldviews more powerful than others" (706). But how those ontological politics worked-specifically, how groundwater models instantiated them--remained mysterious. Because these studies did not follow the models very closely, the role(s) they played in these subsurface debates 
was not entirely clear. Here, I endeavor to keep the NSJB's multiple groundwater models at the center of my analysis.

\section{Methods}

This case study was initially inspired by conversations with NSJB scientists and natural resource managers that took place while I was conducting hydrologic fieldwork in the basin from 2010 to 2012. I have assembled the modeling and policy histories presented here from an assortment of publicly available sources. To develop an understanding of NSJB geology and hydrogeology, I turned to the extensive peer-reviewed literature on the subject, only a modicum of which is cited in the paper. To assess how model-based representations of the NSJB subsurface evolved over time, I closely read and compared reports and technical reviews published on the five models at the heart of the case study, all of which provided descriptions of modeling processes and results (in chronological order, they are: AHA Inc., 2000; Questa Eng. Corp., 2000 \& 2001; Papadopulous \& Assoc. 2006; Norwest Corp. 2009). To trace the legal and regulatory turns of the NSJB groundwater dispute, I collected and reviewed relevant court documents from the Colorado state water courts and Supreme Court, plus rulemaking documents from the Colorado Division of Water Resources. The strength of this policy-document-based analysis is that it traces the epistemic dispute over the NSJB subsurface via the data and discourses presented directly to relevant state and federal decision-makers. The limitation of this analysis, however, is that it does not get all the way inside the model construction process. Following the example of climate change modeling research (Shackley 2001), future studies would benefit from accessing hydrologic consultancies and groundwater model-building teams and the no doubt complex epistemic dynamics underway within them.

\section{Literature Review: Modeling and Governing Hard-To-Know Spaces and Circulations Modeling Hard-To-Know Spaces}

At first glance, the burgeoning STS literature on environmental modeling might seem an odd place to turn for insights on the subsurface. It is focused almost entirely on a system typically described as the underground's opposite: the atmosphere, or, more broadly, the global climate. ${ }^{3}$ And yet the subsurface and atmosphere share many similarities. Both spaces are commons of sorts, housing circulations of crucial natural resources and operating as sinks for a wide variety of pollutants. Both sets of systems also happen to be inscrutable in ways that practically invoke computer-based modeling. They are spatially vast and incredibly complex, and therefore defy study by way of traditional laboratory or experimental settings (Miller \& Edwards 2001; Dahan

\footnotetext{
${ }^{3}$ Another important thread in STS literature on the atmosphere focuses air pollution, including toxics and greenhouse gases. I do not incorporate that literature here because it does not necessarily focus on modeling. Key studies, for example, focus on technologies for visualizing and monitoring air pollution (Fortun et al. 2016; Ottinger 2010) and visualizing air pollution, but they do not directly take up modeling air pollution.
} 
2010), plus changes within them may occur slowly and be invisible to the eye (Moser \& Dilling, 2011). Computer-based models are currently the best tools we have for understanding these systems whole, for predicting change within them, and for signaling and explaining those changes (Edwards 2001). As a result, scientists and the models they produce have become key "spokespeople" for atmospheric and subsurface systems alike. For these similarities and others, the STS literature on global climate modeling is well suited to lend insights to subsurface scholarship.

The core insight of the STS-based literature on climate modeling has been to reveal the many ways, often taken-for-granted, that environmental models co-produce knowledge and politics (Dahan 2010; Demeritt 2001; Hulme 2011; Mahony \& Hulme 2016; Miller \& Edwards 2001). For example, while global climate models have played a critical role in establishing the credibility of the idea that human activities are changing the global climate, they have simultaneously helped to establish basic fundamentals of standing and policy in global warming governance, such as who speaks for the global climate and whether it is even a governable object (Miller \& Edwards 2001). Indeed, the now seemingly obvious concept of global-scale climate change, and the related impetus for a global-scale response, are ideas that found their inspiration and currency in global climate modeling (Miller \& Edwards 2001). The practice of global climate modeling has contributed simultaneously to the development of an epistemic community of people who see the atmosphere as a global commons that deserves protection and to supporting supranational and technocratic approaches to global climate politics (Demeritt 2001; Mahoney \& Hulme 2016). In this sense, global climate models have been central to defining climate change as an environmental problem while also shaping the menu of its potential remedies.

In recognition of global climate modeling's powers of co-production, STS scholar Paul Edwards calls global climate models tools of "world building" (Edwards 2001, 62). The description applies on a few levels. First, because models are the principal tools for understanding global warming they have come to serve as obligatory passage points for scientific and public knowledge, shaping what is known about climate change and how it is known. Second, and perhaps as a result, climate models have become key objects of community building and of conflict. Global climate models have helped create public arenas of shared knowledge, data, tools, and values for consensus building on global warming, while also serving as targets for derailing policy action. In this way, global climate models contribute to the building of political action and inaction. And third, because scenario modeling is the only practical method for assessing the potential effects of policy choices, global climate modeling has become central to weighing various climate governance options. As such, global climate models have become instruments for articulating and enacting competing visions of the world. As Edwards puts it, “Global modeling does not merely represent, but in a social and semiotic sense constructs, the

4 Other major critiques of global climate modeling are that it reduces climate change to a purely physical process (Hulme 2011), that it privileging some variables and knowledges over others (Mahony \& Hulme 2016), and that it is conducted without acknowledgement or discussion of embedded assumptions (Demeritt 2001). 
global atmosphere" (Edwards 2001, 64). In sum, environmental models do much more than provide simplified pictures of nature for policymakers and the public; they shape governance processes from the ground up and influence related socio-ecological outcomes.

\section{Governing the Subsurface}

Senator Moody and other nineteenth century lawmakers chose not to heed John Wesley Powell's suggestions that development of the American West be restricted on account of the region's unreliable surface water supplies. Instead, they encouraged Euro-American settlement and industry, certain that rain would follow farmers' plows (Stegner 1954). When it did not, the federal Bureau of Reclamation stepped in to build water storage systems for the first half of the twentieth century, until big dams lost public support because of their expense and ecological impacts (Reisner 1986). Since the mid-twentieth century, much of the region's growth has been subsidized by unsustainable groundwater use, made possible by the arrival of centrifugal pumping technology and, until recent decades, a relatively laissez faire approach to groundwater governance (Schlager 2006). These trends also apply more broadly. Groundwater use boomed worldwide in the latter part of the twentieth century, particularly to support agriculture and urbanization, and carries on apace (Wijnen et al. 2012). As a result, many governments are now grappling with groundwater overuse and are crafting governance mechanisms to manage pumping, with varying degrees of attention to the complex socio-ecologies and power dynamics bound up in groundwater use (Budds 2009; Birkenholtz 2015).

Many of these new "groundwater governmentalities" (Birkenholtz 2015) have actually been prompted by declines in surface water supplies, much like in the NSJB case introduced above. Groundwater systems often contribute to rivers, which means that over-pumping groundwater can reduce surface water flows and, if it continues, eventually intercept them. Groundwater-surface water interactions often receive attention because surface water systems are likely to already be governed in some way. In the American West, for example, water law governed visible surface water long before it began attending to invisible subsurface water, despite the interconnections between above- and under-ground hydrology in many places (Schlager 2006). This dynamic means that questions of hydraulic connectivity among surface and groundwater sources come up often in groundwater disputes-in Colorado and internationally (Narasimhan 2009). The crucial unknown is usually whether a groundwater source connects to an over-allocated river, and then to what degree. Because sufficient data are usually not available to determine hydraulic connectivity with precision, it is often a legitimate uncertainty (Tidwell \& van den Brink 2008), particularly in areas of CBM production (US National Academy of Sciences 2010).

Groundwater modeling is frequently deployed to address hydraulic connectivity questions, among other common inquiries of groundwater systems. Because it is possible to measure only small slices of an aquifer via borehole sampling or geophysical methods, hydrogeologists turn to computer modeling to interpolate among data points and illustrate broad dynamics (Tidwell \& van den Brink 2008). Advanced as they may be, groundwater models 
embody a number of limitations. As any hydrogeologist will acknowledge, groundwater systems are heterogeneous and complex, and all models are simplifications. Model accuracy depends upon the quality of input data, which in turn depends upon the representativeness of field measurements (Beck et al. 1993; Gaganis \& Smith 2006; Grayson et al. 1992). Groundwater models also embody the subjectivity of modelers, who must make numerous assumptions while modeling. These assumptions begin with the conceptual framework used to start building the model in the first place, conceived from hydrogeologic theory and available data, and carry forward through an iterative and idiosyncratic process of calibration and validation (Beck et al. 1993; Demissie et al. 2008; Kioprogge et al. 2011).

Further confounding the creation and utilization of groundwater models is the fact that models with only slight internal differences can generate significantly different outputs (Oreskes et al. 1994). This conundrum is made even more troublesome by the related quandary that model results are not easily confirmed on the ground through tacit, everyday experience. Changes within groundwater systems are not readily observable to the eye and groundwater itself tends to move very slowly underground. In other words, today's pumping activities may not be clearly manifested tomorrow; they might not be felt for decades or longer. The result is a decoupling of cause and effect in time and space that makes it especially difficult to know if a model's predictions are correct (Eaton 2010). In many cases, future generations will be the ones to find out if today's groundwater models were right. Hydrogeologists widely acknowledge these limitations, and stress that decision making about groundwater management should always incorporate multiple lines of evidence and not be based solely on models (Oreskes et al. 1994; Tiwell \& van den Brink 2008). Despite these cautionary statements, policymakers have come to increasingly rely upon models as decision-making tools (Bolin et al. 2008; Budds 2009; Holifield 2009).

\section{Case Study: The Northern San Juan Basin Coalbed Methane Produced Water Dispute A Contest of Two Subsurface Visions}

The question at the heart of the NSJB case was about more than whether the CBM industry was depleting surface water systems with its produced water withdrawals. It was also about whether produced water should be governed just like other groundwater in the state of Colorado. Until the NSJB dispute came along, Colorado water law essentially ignored the water withdrawn from underground by oil and gas operations. This was in many ways a departure from the state's typical water customs, which involve carefully managing water use. Most of Colorado's water governance follows a legal doctrine that assigns water rights based on seniority in time of use-both for surface water and for the shallow groundwater that feeds surface water systems, known under Colorado law as "tributary" groundwater (Jones \& Chech 2009). Despite this strict approach, produced water ran under the water law radar for many decades as a waste product to be overseen by state oil and gas regulators (Thorne \& Caile 2012). Energy companies trucked away this groundwater without attending to the possibility that, in some places, they could be depriving senior water rights holders of flows on over-appropriated streams. 
The groundwater dispute in the NSJB eventually reversed this exception, enrolling produced water into the state's existing water governance regime. Here, I relay the history of how produced water came to be counted in Colorado. It is a story of subsurface stakeholders at odds with each other in an array of legal and regulatory venues, where they debated questions of hydraulic connectivity. These questions were specific to the NSJB in some ways but transcend location in many more, since the impacts and governance of produced water withdrawals are uncertain and contentious at sites of oil and gas production around the world (US National Academy of Sciences, 2010; deRijke et al. 2016), and since hydraulic connectivity debates between groundwater and surface water users occur in municipal and agricultural settings in addition to energy development contexts (Budds, 2009; Hollifield, 2009). The NSJB case is also a story of how two opposing visions of the subsurface were contested and eventually combined, and how computer-based groundwater models factored into that process-serving as mathematical proving grounds where stakeholders of the subsurface tested and contested differing conceptions of the NSJB's inner workings. Here, I trace this contest of subsurface representations as it took place across NSJB modeling efforts from 1999 to 2009.

\section{Fruitland Formation Modeling Begins}

In 1999, a team of federal and state natural resources regulators launched a multi-year modeling endeavor called the $3 \mathrm{M}$ Project ${ }^{5}$ that they hoped would clarify Fruitland Formation dynamics and resolve concerns about produced water withdrawals in the NSJB. ${ }^{6}$ The 3M Project's first step was to assemble a technical supervisory team made up of representatives from state, federal, and tribal agencies, plus the CBM industry, and to commission two water resources consultancies to develop two models based on data provided by industry members and regulators: a model of regional groundwater flows in the NSJB (AHA 2000) and a model of the basin's natural gas reservoir (Questa 2000). Once commissioned, the consultancies got to work trying to bring the basin's depths to life in a computerized form. Immediately, they faced an intellectual and political hurdle.

Every groundwater model has to start from something, and that something is a conceptual framework of how one envisions the subsurface system to operate. In the NSJB in 1999, two opposing conceptual frameworks existed to describe Fruitland Formation hydrogeology. The two frameworks differed in their interpretations of hydraulic connectivity, and were known in policy circles as the Hydraulically Connected Basin and the Hydraulically Compartmentalized Basin frameworks (SJPLC 2006). The Connected Basin framework posited that the Fruitland Formation was hydraulically connected within itself and that it also linked to local surface water sources (Figure 2). Under the Connected Basin model, some of the groundwater in

\footnotetext{
s The three "Ms" stood for "Mapping," "Modeling," and "Monitoring."

"Concerns about methane emissions from the Fruitland Outcrop to the atmosphere also drove modeling efforts, but are outside the scope of this paper.

"A more common term in hydrogeology is "conceptual model," but since the word "model" appears so often in this article, I have substituted the word "framework" for clarity's sake.
} 
the Fruitland Formation contributed to rivers where they cut across the Fruitland Outcrop and some flowed slowly into the basin's depths and south toward its lowest point, the San Juan River in New Mexico. The Compartmentalized Basin framework embodied the opposite assumption: that groundwater flow was quite limited within the Fruitland Formation because of low permeability, faults, and other geologic barriers (Figure 3). The implication of the Connected Basin framework was that pumping produced water from Fruitland Formation would impact surface water rights, while the Compartmentalized Basin framework suggested that it would not (Table 1).

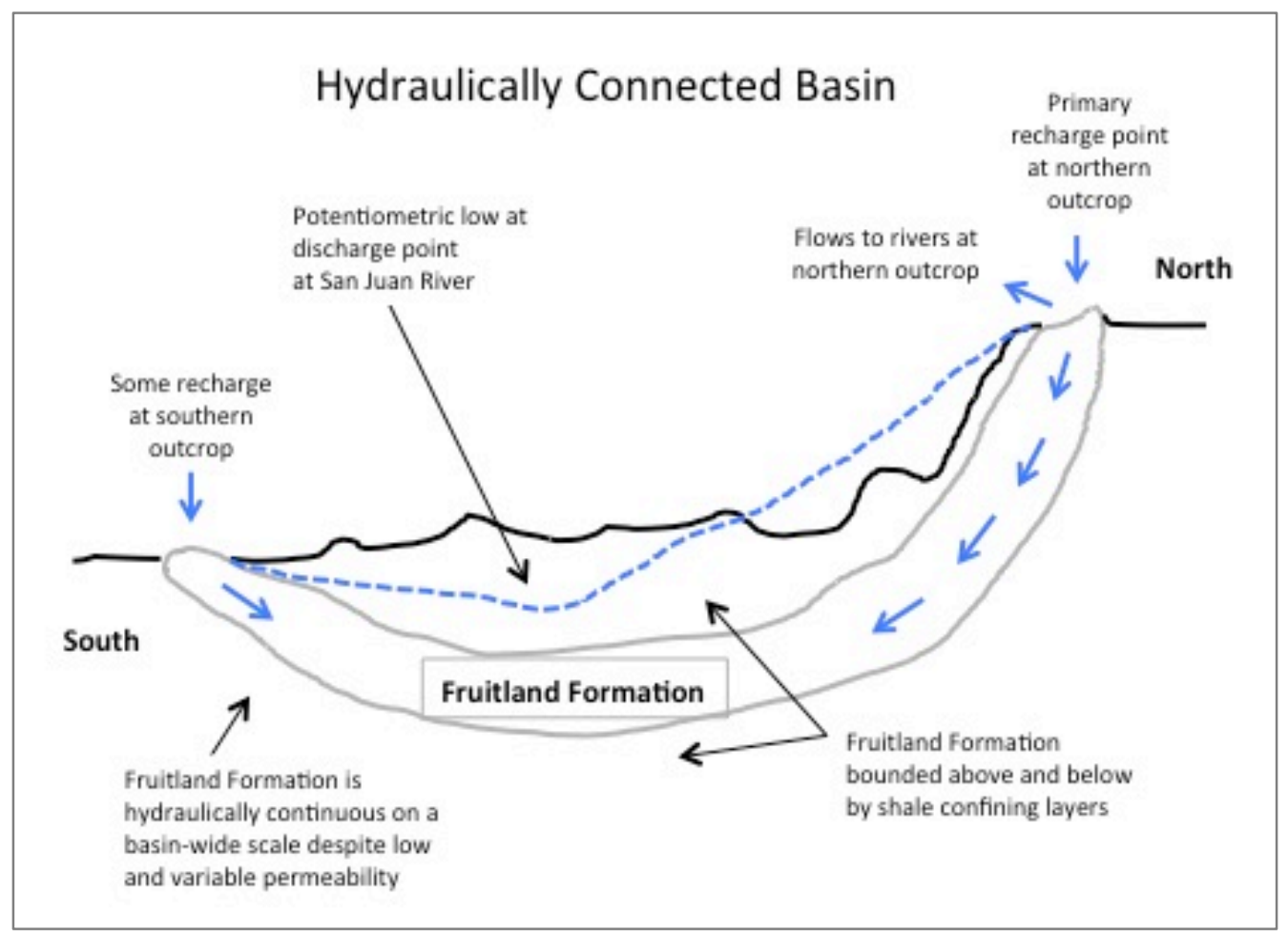

Figure 2. Schematic of the Hydraulically Connected conceptual framework of the Northern San Juan Basin. Sketch adapted from Applied Hydrology Associates (2000).

Each conceptual framework of the NSJB subsurface had its champions at the outset of the 3M Project, as explained in technical reports published on the modeling process (Questa 2000) and by federal resource managers in later summaries (SJPLC 2006). The Connected Basin framework had hydrogeologic theory on its side, since it is the traditional conceptual framework for a confined aquifer such as the Fruitland Formation, which is sandwiched between two layers of shale (Fetter 2001). Existing geochemical and geophysical data also supported the concept, as 
did anecdotal evidence and observations by natural resource managers and local groundwater users in the basin (SJPLC 2006). The Compartmentalized Basin framework had the CBM industry behind it. In fact, CBM industry representatives forwarded the Compartmentalized Basin framework at the outset of the modeling effort, suggesting that more barriers to groundwater flow existed than the Connected Basin framework assumed (Questa 2000). CBM producers lacked data to definitively support the concept, however, leaving the consultants to figure out what to do (Questa 2000).

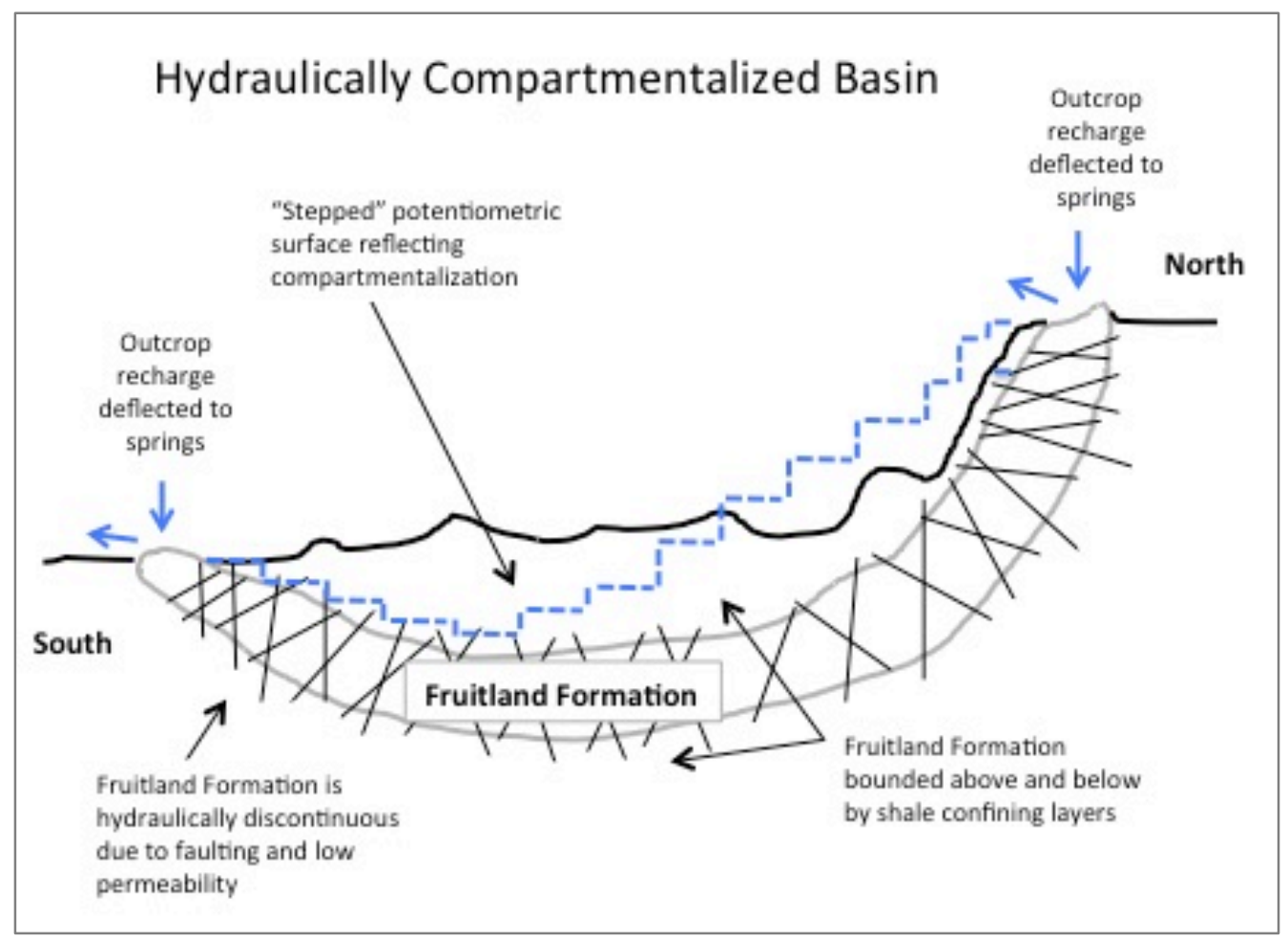

Figure 3. Schematic of the Hydraulically Compartmentalized conceptual framework of the Northern San Juan Basin. Sketch adapted from Applied Hydrology Associates (2000).

In order to find the correct starting point for their subsurface representations, the modelers at AHA made their first task the evaluation of the dueling conceptual frameworks that they had been presented (AHA 2000; Questa 2000). AHA ran simulations of the two conceptual frameworks and compared the results to available field data. Through these modeling exercises, the model builders found themselves negotiating the basic contours of the subsurface world beneath southwestern Colorado. In the process, they were also deciding between contrasting versions of that subsurface world presented by general hydrogeologic theory and by the CBM 
industry. After trying both frameworks, AHA determined that the Hydraulically Connected Basin model produced results that most closely matched existing empirical data. In AHA's words, the modeling exercise suggested that the Fruitland Formation behaved simply and consistently "like a classic confined aquifer system, which is regionally interconnected despite the presence of structural and stratigraphic discontinuities" (2000). The modelers estimated that the Fruitland contributed approximately 200 acre-feet of water to local rivers per year. Later models estimated that the CBM industry was intercepting the bulk of these flows (Questa, 2001).

\begin{tabular}{|l|l|l|}
\hline Groundwater Issue & $\begin{array}{l}\text { Hydraulically } \\
\text { Connected Basin }\end{array}$ & $\begin{array}{l}\text { Hydraulically } \\
\text { Basin }\end{array}$ \\
\hline $\begin{array}{l}\text { Groundwater level declines } \\
\text { near Fruitland Outcrop. }\end{array}$ & $\begin{array}{l}\text { CBM-related groundwater } \\
\text { withdrawals from the Fruitland } \\
\text { Formation can cause declines in } \\
\text { groundwater levels near the } \\
\text { Outcrop. }\end{array}$ & $\begin{array}{l}\text { CBM-related groundwater } \\
\text { withdrawals from the Fruitland } \\
\text { Formation have no effect on } \\
\text { groundwater levels near the Outcrop. }\end{array}$ \\
\hline $\begin{array}{l}\text { Reduction in groundwater } \\
\text { discharge from the Fruitland } \\
\begin{array}{l}\text { Formation to area rivers and } \\
\text { streams. }\end{array}\end{array}$ & $\begin{array}{l}\text { CBM-related groundwater } \\
\text { withdrawals from the Fruitland } \\
\text { Formation will intercept } \\
\text { groundwater that would } \\
\text { normally discharge to area } \\
\text { rivers and streams, and will } \\
\text { therefore decrease baseflow to } \\
\text { those rivers. }\end{array}$ & $\begin{array}{l}\text { CBM-related groundwater } \\
\text { withdrawals from the Fruitland } \\
\text { Formation have no effect on } \\
\text { groundwater discharge to area rivers } \\
\text { and will have no effect on baseflow in } \\
\text { the rivers. }\end{array}$ \\
\hline $\begin{array}{l}\text { Declines in natural spring } \\
\text { flow from springs sourced by } \\
\text { the Fruitland Formation and } \\
\text { issuing from the Outcrop. }\end{array}$ & $\begin{array}{l}\text { CBM-related groundwater } \\
\text { withdrawals from the Fruitland } \\
\text { Formation may cause declines } \\
\text { in natural spring flow or } \\
\text { drying up of springs. }\end{array}$ & $\begin{array}{l}\text { CBM-related groundwater } \\
\text { withdrawals from the Fruitland } \\
\text { Formation do not affect natural } \\
\text { springs. }\end{array}$ \\
\hline
\end{tabular}

Table 1. Table comparing differing potential impacts of CBM development based on the assumptions of the Connected Basin and the Compartmentalized Basin Conceptual frameworks, adapted from SJPLC (2006).

These conclusions had a real impact. The water resource consultancies' adoption of the Connected Basin framework served as a key analytical input for the federal EIS process evaluating new drilling proposals. But the Compartmentalized Basin concept did not disappear. As the SJPLC pursued its EIS analysis, a geoscientist for the largest CBM operator in the basin, BP American Production Corp., submitted a new study that put the Compartmentalized Basin framework back on the table. In a project undertaken partly under the auspices of the 3M Project and partly outside of it, a BP geoscientist evaluated the geochemistry of produced water collected from 100 CBM wells in the NSJB and published a study arguing that the water was about 60 million years old (Riese et al. 2005). The study contended that the Fruitland was a largely static hydrologic system disconnected from the rest of the basin, implying that the 3M Project modeling had been incorrect and that CBM production had no impact on local rivers. Other geoscientists 
went on to contest the study's methods and interpretations (Zhou \& Ballentine 2005), but BP's empirical challenge forced federal natural resources managers to wrestle with the dueling conceptual frameworks again.

After weighing the competing subsurface visions before them, the federal agencies chose the 3M Project model results over BP's empirics, carrying on with the assumption of hydraulic connectivity in their EIS process. The agencies reasoned that the 3M Project models had been built upon a large dataset, and that they were supported by widely accepted scientific assumptions about confined aquifer dynamics, peer-reviewed literature supporting hydraulic connectivity, and anecdotal observations and field data collected by local, state, and federal agencies. The SJPLC officials concluded that Riese et al.'s conceptual framework, on the other hand, had been "developed from 100 data points of poorly understood geochemical data" (2006, 3-21). The Compartmentalized Basin framework shifted to the side, for the time being.

\section{The Fruitland Formation Goes to Court}

Perhaps most importantly, AHA and Questa's model results demonstrating hydraulic connectivity and stream depletions also inspired a lawsuit. After noticing reduced flows in the springs and streams for which they had senior water rights, and after seeing the 3M Project model results in the SJPLC's draft EIS statement, two ranching families teamed up and filed a complaint in the basin's water court (Klahn 2005). In the lawsuit, the ranchers claimed that CBM development was injuring their water rights and argued that CBM industry's use of groundwater should be governed squarely under Colorado's water rights system. The ranchers wanted the CBM industry to be legally required to replace any groundwater they withdrew from the Fruitland Formation that might normally feed local rivers. The case brought the BP study--and the CBM industry's interpretations of the subsurface as a hydraulically compartmentalized system--back into play. BP submitted its empirical challenge to the legal proceeding in an effort to push back against the rancher's water rights claims in water court and, eventually, at the Colorado Supreme Court (Miller 2006).

After a decade of modeling efforts and empirical challenges over the NSJB's inner workings, the state Supreme Court ultimately decided in favor of the ranchers and the Connected Basin model in 2009 (Vance v. Wolfe 2009). That decision enrolled produced water into Colorado's water rights system for the first time-not just for the NSJB's Fruitland Formation, but for hydrocarbon-bearing swaths of the subsurface statewide. ${ }^{s}$ The court ruling created a big job for the Colorado Division of Water Resources (DWR): determining, for every known oil-and-gasproducing geologic formation in the state, which parts of the formation contributed groundwater to streams and which parts did not. In legal vernacular, DWR needed to make "tributary" or "non-tributary" designations for much of Colorado's subsurface and then to permit tens of thousands of oil and gas wells as though they were water wells according to those designations.

${ }^{8}$ Ironically, the court made its decision not on the scientific merits of the $3 \mathrm{M}$ Project groundwater models, but based on a presumption in Colorado law that groundwater is connected to streams until proven not to be. In other words, the growing collection of NSJB models did not directly shape the court's decision. 
Oil and gas wells that withdrew groundwater in "tributary" zones would need a formal plan for replacing groundwater depletions in order to protect senior water rights holders. Wells withdrawing groundwater in "nontributary" zones would not have to replace their depletions, but they would have to be permitted and monitored.

\section{More Models Needed}

The court-ordered task of assigning tributary or non-tributary groundwater status to Colorado's oil and gas zones spurred two further rounds of groundwater modeling. The first round of modeling was quick, and by everybody's standards, also too simple. In anticipation of the Vance v. Wolfe court decision, DWR got a jump on discerning tributary and nontributary zones in Colorado's CBM fields by commissioning a third water resources consultancy, S.S. Papadopulos \& Associates, Inc., to develop a first-order estimate of tributary groundwater boundaries across the state (Papadopulos 2006).

As they embarked on their analysis, the Papadopulos consultants found themselves in the position that AHA and Questa had been in several years earlier: having to address the dueling conceptual frameworks of the NSJB before they could move forward in their analysis. The consultants took a new turn in doing this, which they explained in their final report (Papadopulos 2006). Instead of choosing between the two conceptual models, as others had done, the Papadopulos analysts merged them. The Fruitland Formation could be both hydraulically connected and compartmentalized at the same time, they argued, by being hydraulically connected in some areas but not others. In their final report, the Papadopulos analysts made a case for why the two frameworks were not that far apart. "The models do not represent substantially different flow dynamics," they wrote. The differences between them were "primarily a matter of degree" $(2006,22)$.

The Papadopulos consultants then set about trying to quantify stream depletions from CBM development and trying to determine where connectivity between the Fruitland Formation and local rivers started and stopped--in other words, which regions should be considered tributary and which should be considered nontributary for groundwater governance. At DWR's behest, the consultants arrived at these determinations by applying a simple equation developed in the 1950s called the Glover Balmer method. Because administering groundwater permits for oil and gas wells across the state would be a massive undertaking, DWR wanted to see if this simple analytical tool would be up to the task. The Papadopulos analysts came up with a tributary groundwater boundary of about $17 \mathrm{~km}(10.5 \mathrm{mi})$ downstream of the Fruitland Outcrop. Following these conclusions, groundwater inside of 10.5 miles from the outcrop would be considered tributary, while groundwater beyond it would be considered nontributary. Several hydrogeologists commented on the results as part of a technical review process; all criticized the Glover Balmer analysis for oversimplifying a complex system. Technical reviewers said the

- The Glover Balmer equation solves for the ratio of stream depletion to total pumpage. It assumes the well pumping from an aquifer that is fully connected to a stream, among many other simplifying assumptions (Glover et al. 1954). 
model was a poor choice for such an important rulemaking process, but they disagreed over its shortcomings, with some arguing that the stream depletion calculations were an underestimate and others arguing the opposite.

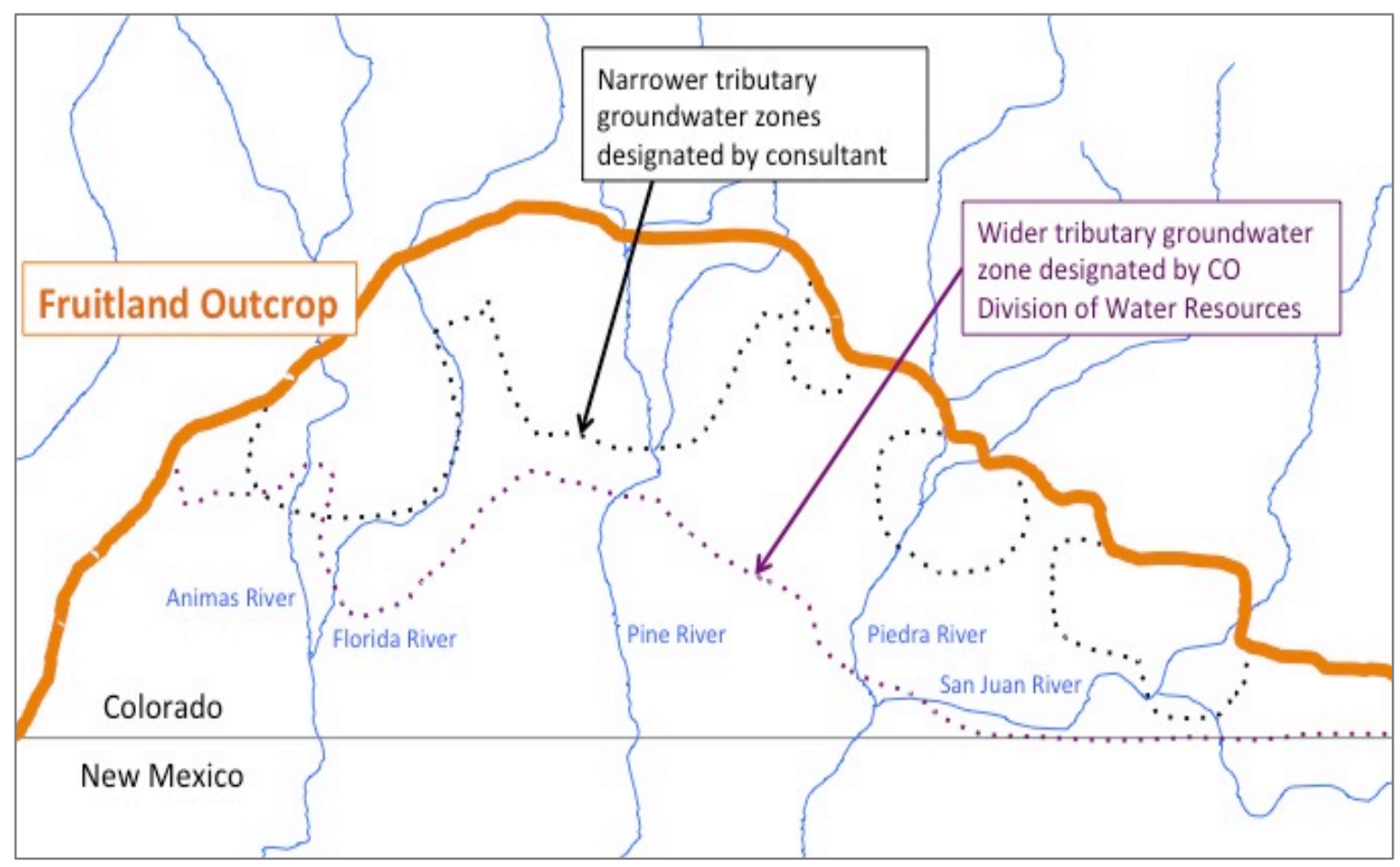

Figure 4. Narrower tributary boundaries submitted by Norwest Corp. to Division of Water Resources rulemaking (in black), superimposed upon the wider tributary boundaries derived from the Papadopulos stream depletion assessment (2006) using the Glover Balmer analytical method (in purple). Map adapted from Norwest Corp. (2009) and DWR Final Produced Nontributary Ground Water Rules (2010); boundaries are estimates.

After commissioning the Glover Balmer assessment, DWR said it would allow stakeholders to submit more sophisticated models and their outputs to its rulemaking process as "proposed alternate rules" (DWR 2010). The CBM industry took the opportunity. As the rulemaking got underway in 2009, a cohort of CBM industry members commissioned a fourth water resources consultancy, Norwest Corp., to submit a new NSJB groundwater model intended to supplant the state-commissioned Glover Balmer analysis (Norwest 2009). Norwest had merged with two of the previously mentioned consultancies, AHA and Questa, and had combined their water resources consulting businesses. DWR accepted Norwest's model in the rulemaking as being superior to its own analysis, which it was. The industry-submitted model reduced oil and gas operators' newfound responsibilities for replacing produced water 
withdrawals by shrinking the Fruitland Formation's tributary designation-from roughly 10.5 miles from the Fruitland Outcrop to 0-8 miles in various locations (Norwest 2009) (Figure 4).

DWR adopted the nontributary boundaries forwarded by Norwest's NSJB model after a technical peer review process and multiple rounds of testimony provided by expert hydrogeologists, which included debates over data inputs, recharge rates, and the influence of various confining layers and dikes (DWR 2010). After taking all of the testimony and evidence into account, the State Engineer determined the model "to be well-conceived" and to provide "clear and convincing evidence" in support of the proposed nontributary boundaries, citing the extensive data behind it, its thorough calibration, and peer review (2010, 5). Perhaps unsurprisingly, this decision initiated a new round of litigation-this time by a wider cohort of water-rights-holders from across the state who argued that they were not given enough opportunity to review Norwest's model in the DWR rulemaking process and comment on its accuracy (Klahn 2010). Their legal challenge was not successful (Pawnee Well Users v. Wolfe 2011).

\section{Discussion: Groundwater Models as Builders of (Sub)Surface Worlds}

As the NSJB case illustrates in several ways, scientists' ability to "see in the ground farther" than before has not led directly to epistemic consensus about subsurface dynamics. Indeed, more than a hundred years after Senator Moody's run-in with the United States' chief geologist, John Wesley Powell, subsurface stakeholders' still frequently disagree over what is happening in underground systems, despite the past century's proliferation of boreholes and increasingly sophisticated subsurface tools. Drawing from the STS literature on global climate modeling, I argue that this is because groundwater models are more than simulations of subsurface dynamics. Rather than viewing groundwater models as simplified pictures of nature with which to make policy decisions, we are better off understanding them as "world builders"--as tools that embed, enact, and circumscribe subsurface politics as they produce subsurface knowledge and shape socio-ecological outcomes. I use the NSJB case to elaborate upon each of these points below.

In terms of embedding subsurface politics, the models built to simulate Fruitland Formation dynamics in the NSJB literally refereed among stakeholders' competing subsurface projections. Individually and collectively, the five models at the core of the NSJB groundwater dispute adjudicated between opposing conceptions of the NSJB's inner workings that aligned with the interests of either surface water rights holders or the CBM industry. Models played this role because the debate about hydraulic connectivity in the NSJB was always about more than hydrogeology, and because the key difference between the Connected and Compartmentalized Basin frameworks was always more than physical. The difference was also about legal standing-if the groundwater being produced from CBM wells "belonged" to anybody, and whether produced water should be made legible to Colorado's water rights system and managed accordingly. As AHA and Questa developed early models of NSJB subsurface dynamics, they were drawing lines of eventual rights and responsibilities. As negotiators of subsurface worlds, 
the groundwater models of the NSJB subsurface became instruments for weighing--and eventually merging-dueling accounts of the underground that had different implications for subsurface stakeholders with competing groundwater objectives.

The NSJB models projected differing conceptions of Fruitland Formation hydraulic connectivity into mathematical space and sought a best fit with available empirical data and hydrogeologic theory. In the process, model results lent credence to particular subsurface stakeholders and their claims to water. The first models developed under the $3 \mathrm{M}$ Project in the early 2000s by AHA and Questa provided support for the hydraulic connectivity concerns of local ranchers with senior water rights and others who worried about groundwater drawdown by CBM development. In the process, those models also dismissed the CBM industry's vision of the NSJB as a hydraulically compartmentalized area that supported consequence-free produced water withdrawals. Later models developed for DWR's groundwater management rulemaking in the by Papadopulos and Norwest embedded both sets of ideas and arguments.

In terms of enacting subsurface politics, groundwater model results shaped socioecological relations above and under the ground by supporting governance decisions that shaped hydrologic flows in particular ways. After 2010, in the eyes of DWR, all of the CBM wells in the state of Colorado became both water wells and natural gas wells. The lines that Norwest's models drew to designate tributary from nontributary zones established new limits for CBM industry groundwater pumping from the Fruitland Formation, particularly for wells on the "tributary" side of the border. CBM wells in tributary zones suddenly faced pumping restrictions and requirements that they replace any produced water withdrawals that might impact senior water rights holders. The water balance in the NSJB has been different in the seven years since 2010 than it would have been otherwise.

Groundwater models also worked to circumscribe subsurface politics in several important ways. As a starting point, regulators' reliance on models as key inputs for governance decisions set basic terms of who could speak for the subsurface by advantaging the analyses and interpretations of those who had the technical prowess to render underground dynamics legible in computerized form. In this case, all of the hydrogeologists possessing such technological prowess built subsurface models from private sector stations. Modelers at four different water resources consultancies became crucial translators and interpreters of subsurface dynamics. In doing so, they embodied a broader trend toward the privatization of hydrologic knowledge production, which has thus far been studied primarily in different US water resources contexts, including ground water quality monitoring (Kinchy 2014) and stream restoration (Lave 2012).

The ownership of boreholes also shaped participation in the governance process. In the NSJB case, as in many subsurface monitoring and governance cases, the bulk of the subsurface data collection system was the extractive network itself. The thousand-plus CBM wells that had been drilled in the NSJB collectively served as its largest window, even though they had been designed for optimal resource retrieval rather than optimal knowledge production. Statemanaged monitoring wells were few and provided much less data by comparison. As a result, resource extractors--those plying the NSJB depths for particular products and outcomes-occupied an especially privileged position in knowledge production. The Riese et al. (2005) 
geochemical study serves as the clearest example of this dynamic. The BP geoscientist had access to $\mathrm{CBM}$ wells and financial backing that enabled research activities that challenged the growing momentum of the Connected Basin conceptual framework. Ultimately, regulators and other scientists rebuffed the study (SJPLC 2006; Zhou \& Ballentine 2005), but it succeeded in putting the Compartmentalized Basin framework on the table in multiple regulatory and legal venues.

In the context of the NSJB case, Senator Moody's 1890s retort that those with holes in subsurface are apt to see the farthest might therefore be more prescient than originally intended. This point is worth examining, particularly because the gravity of private sector data and analyses appears to be a key difference between underground and above-ground modeling practices. As the NSJB case and others demonstrate, groundwater models often rely heavily upon private sector data inputs and model-building capacity--much more so than do global climate models. Whereas global climate models are constructed by teams of scientists at national laboratories based on data gathered from a monitoring network that has been coordinated over time by global scientific organizations (Miller 2001; Shackley 2001), models of the subsurface may be built by private sector water resources consultancies from data gathered primarily from networks of extractive sites that range from oil and gas wells to individual water wells (Bolin et al. 2008; Budds 2009; Holifield 2009).10 The private nature of this data sourcing and knowledge production appears to reduce trust and exacerbate epistemic disputes over subsurface dynamics, as demonstrated in the NSJB case by the 2010 lawsuit against Norwest's model and DWR's rulemaking process.

\section{Conclusion}

The epistemic complexities just discussed make it even more difficult to know what to think of the hybridized conceptual framework that came to define the NSJB in 2010. In their final tributary and non-tributary groundwater designations, had consultants and natural resource managers arrived at a reliable representation of subsurface dynamics? Did the predictions of NSJB groundwater models become more accurate as models grew in number and sophistication with time? Are senior surface water rights being protected in the manner intended by the new rules and groundwater management designations? The subsurface's inscrutabilities-its opaqueness; its vast, heterogeneous, and slow-moving nature; and the ontological politics involved in rendering its depths legible for governance-make it hard to say for sure. The best hope that natural resource managers have for judging the predictions of the NSJB models is to monitor surface-groundwater interactions at the Fruitland Outcrop for change over time, the task that sent me wading into NSJB rivers in 2010.

Given the fact that groundwater is the most extracted resource in the world, and the persistent inscrutability of the subsurface, perhaps another set of questions is in order. When engaging a resource such as groundwater that is as contestable and invisible as it is essential, an

${ }_{10}$ Private consultancies are not the chief modelers in all groundwater cases. The US Geological Survey or state geologic surveys play this role as well, depending on the groundwater case. 
alternative line of inquiry is to ask just how much precaution should be taken in the face of subsurface uncertainties, unknowns, and ontological politics. For example, if we won't know for sure what the surface water impacts of a particular form of groundwater extraction will be for another decade or more, should we err toward less pumping? Public discussion of this question did not appear as a central feature in the regulatory and legal documents at the heart of the NSJB decision process. As is common in "scientized" debates (Sarewitz 2004), disputes centered on model results and model uncertainties rather than human values in risk-taking or precaution.

As models and their architects speak for the subsurface, then, they work to circumscribe subsurface politics in yet another way that should be acknowledged. Models act as "world builders" without much discussion of what kind of worlds-under the ground and above it-we ought to build. Short of that conversation, it is hard to imagine competing subsurface stakeholders' arrival at a shared definition of underground space and their impacts upon it, per common pool resource theory (Ostrom, 1990). By comparison, it is relatively easy to picture the persistence of dueling models in important conversations about subsurface stewardship, and another century of Senator Moody-like arguments about whether we have enough holes in the ground to know anything for sure. This may be good news for the hydrogeologists who would remain gainfully employed as a result. But for all of us whose fates are entwined with complex subsurface socio-ecologies and evolving groundwater governmentalities, it is becoming increasingly important to acknowledge that our growing capabilities of "seeing" underground will not, on their own, reveal the most sustainable, equitable, and broadly agreeable ways forward.

\section{Acknowledgements}

Many thanks to Dr. Mark Williams (University of Colorado) and The Mountain Studies Institute staff (Durango, Colorado) for their logistical support and mentoring of the 2010-2012 hydrologic fieldwork and analysis that served as the gateway to the work presented here, and to the University of Colorado Chancellor's Fellowship and University of Colorado Office of University Outreach for funding that made it possible. My gratitude also to the conveners of, and fellow participants in, the much more recent 2017 STS Underground workshop held at the Colorado School of Mines; I greatly appreciated your insightful and constructive feedback on earlier drafts of this manuscript. Of course, any errors or omissions are the author's responsibility alone.

\section{Author Biography}

Adrianne Kroepsch is an Assistant Professor in the Humanities, Arts, and Social Sciences Division at the Colorado School of Mines, where she studies and teaches about environmental governance with an emphasis on the roles of data, discourse, and deliberation. 


\section{References}

Applied Hydrology Associates, Inc. (AHA). 2000. 3M Project San Juan Basin, Colorado and New Mexico: Hydrologic Modeling Report. Denver, CO: Applied Hydrology Associates, Inc.

Beck, M., Jakeman, A., \& McAleer, M. 1993. "Construction and evaluation of models of environmental systems." In Modelling Change in Environmental Systems, edited by A. Jakeman, M. Beck, and M. McAleer. Chichester: Wiley.

Birkenholtz, T. 2008. "Contesting expertise: The politics of environmental knowledge in northern Indian groundwater practices." Geoforum, 39(1), 466-482.

Birkenholtz, T. L. 2015. Recentralizing groundwater governmentality: rendering groundwater and its users visible and governable. Wiley Interdisciplinary Reviews: Water, 2(1), 21-30.

Bolin, B., Collins, T., \& K. Darby. 2008. "Fate of the Verde: water, environmental conflict, and the politics of scale in Arizona's central highlands." Geoforum, 39(3), 1494-1511.

Bowker, G. C. 1994. Science on the run: Information management and industrial geophysics at Schlumberger, 1920-1940. Cambridge: MIT Press.

Budds, J. 2009. "Contested H2O: Science, policy and politics in water resources management in Chile." Geoforum, 40(3), 418-430.

Dahan, A. 2010. "Putting the Earth System in a numerical box? The evolution from climate modeling toward global change." Studies in History and Philosophy of Science Part B: Studies in History and Philosophy of Modern Physics, 41(3), 282-292.

de Rijke, K., Munro, P., \& M. Zurita. 2016. "The Great Artesian Basin: A contested resource environment of subterranean water and coal seam gas in Australia." Society $\mathcal{E}$ Natural Resources, 29(6), 696-710.

Demeritt, D. 2001. "The construction of global warming and the politics of science." Annals of the association of American geographers, 91(2), 307-337.

Demissie, Y.K., Valocchi, A.J., Minsker, B.S., \& B.A. Bailey. 2009. "Integrating a calibrated groundwater flow model with error-correcting data-driven models to improve predictions." Journal of Hydrology, 364(3-4), 257-271.

Division of Water Resources, Colorado (DWR). 2010. "Rule 17.7.D. -- Statement of Basis, Purpose, and Specific Authority; Discussion of Specific Concerns Regarding Basin-Specific Rules." Final Nontributary Ground Water Rules, February 12, 2010. Retrieved from http: / / water.state.co.us/groundwater/GWAdmin/NontribGW / Archive/ Pages / Nontrib GWArchivedRules.aspx

Edwards, P. 2001. "Representing the Global Atmosphere: Computer Models, Data, and Knowledge about Climate Change." In Changing the Atmosphere: Expert Knowledge and Environmental Governance, edited by C. Miller and P. Edwards. 31-66. Cambridge: MIT Press.

Fetter, C. W. 2001. Applied Hydrogeology (4t edition). London: Pearson

Fortun, K., Poirier, L., Morgan, A., Costelloe-Kuehn, B., \& M. Fortun. 2016. "Pushback: Critical data designers and pollution politics." Big Data \& Society, 3(2), 2053951716668903.

Frehner, B. 2011. Finding Oil: The Nature of Petroleum Geology, 1859-1920. Lincoln: University of 
Nebraska Press.

Gaganis, P., \& L. Smith. 2006. "Evaluation of the uncertainty of groundwater model predictions associated with conceptual errors: A per-datum approach to model calibration." Advanced Water Resources, 29(4), 503-514.

Grayson, R., Moore, I., \& T. McMahon. 1992. "Physically based hydrologic modeling 2: is the concept realistic?" Water Resources Research, 28(10), 2659-2666.

Hansen, A. \& D. Machin. 2013. "Researching Visual Environmental Communication." Environmental Communication, 7:2, 151-168, DOI: 10.1080/17524032.2013.785441

Holifield, R. 2009. "How to speak for aquifers and people at the same time: Environmental justice and counter-network formation at a hazardous waste site." Geoforum, 40(3), 363-372.

Hulme, M. 2011. "Reducing the future to climate: a story of climate determinism and reductionism." Osiris, 26(1), 245-266.

Jones, A.P. \& T. Chech. 2009. Colorado Water Law for Non-Lawyers. Boulder, CO: University Press of Colorado.

Kinchy, A.J. 2014. Political Scale and Conflicts Over Knowledge Production: The Case of Unconventional Natural Gas Development. Routledge Handbook of Science, Technology, and Society. New York: Routledge.

Kioprogge, P., van, d. S., JP, \& A.C. Petersen. 2011. A method for the analysis of assumptions in model-based environmental assessments. Environ Modelling Software, 26(3), 289-301.

Klahn, S. 2005. Plaintiffs' Complaint for Declaratory Judgment, Case No. 05CW63. Durango, CO: District Court, Water Division 7.

Klahn, S. 2010. Plaintiffs' and Plaintiff-Intervenors' Opening Brief, Case No. 2010CW80. Greeley: District Court, Water Division No. 1.

Lave, R. 2012. Fields and Streams: Stream Restoration, Neoliberalism, and the Future of Environmental Science. Athens, GA: University of Georgia Press.

Mahony, M., \& M. Hulme. 2016. "Epistemic geographies of climate change science, space and politics." Progress in Human Geography, 0309132516681485.

Miller, Z. C. 2006. BP America Production Co. Motion for Summary Judgment, Case No. 05CW63. Durango, CO: District Court, Water Division No. 7.

Miller, C. 2001. "Scientific Internationalism in American Foreign Policy: The Case of Meteorology, 1947-1958." In Changing the Atmosphere: Expert Knowledge and Environmental Governance, edited by C. Miller and P. Edwards. 167-218. Cambridge: MIT Press.

Miller. C \& P. Edwards. 2001. "Introduction: The Globalization of Climate Science and Climate Politics." In Changing the Atmosphere: Expert Knowledge and Environmental Governance, edited by C. Miller and P. Edwards. 1-31. Cambridge, MA: MIT Press.

Moser, S. C., \& Dilling, L. 2011. "Communicating climate change: closing the science-action gap." The Oxford Handbook of Climate Change and Society, 161-174. Oxford University Press, Oxford.

Narasimhan, T. N. 2009. "Groundwater: from mystery to management." Environmental Research Letters, 4(3), ARTN 035002. doi:10.1088/1748-9326/4/3/035002

Norwest Corp. 2009. Northern San Juan Basin Groundwater Modeling Project Final Report. Denver, 
CO: Norwest $\quad$ Corp. $\quad$ Retrieved from ftp:/ / dwrftp.state.co.us/dwr/Produced_Nontributary.../digital_.pdf

Oreskes, N., Shrader-Frechette, K., \& K. Belitz. 1994. "Verification, validation, and confirmation of numerical models in the earth sciences." Science, 263(5147): 641-646.

Ostrom, E. 1990. Governing the commons: The evolution of institutions for collective action. Cambridge: Cambridge University Press.

Ostrom, E. 1964. Public Entrepreneurship: A Case Study in Ground Water Basin Management. PhD diss., University of California, Los Angeles.

Ottinger, G. 2010. "Buckets of Resistance: Standards and the Effectiveness of Citizen Science." Science, Technology, and Human Values, 35(2): 244-270.

Papadopulos \& Associates, Inc. 2006. Coalbed Stream Depletion Assessment Study - Northern San Juan Basin, Colorado. Boulder, CO: Papadopulos \& Associates, in conjunction with Colorado Geological Survey. Retrieved from cogcc.state.co.us/Library/SanJuanBasin/CMSDA_Study.pdf

Pawnee Well Users v. Wolfe. 2011. Water Division No. 1, District Court. Case No. 10CW80, September 8, 2011.

Questa Engineering Corp. 2000. The 3M CBM Final Report, Volumes I and II. Golden, CO: Questa Engineering Corp.

Questa Engineering Corp. 2001. San Juan Basin Ground Water Modeling Study: Ground Water -Surface Water Interactions Between Fruitland Coalbed Methane Development and Rivers. Golden, CO: Questa Engineering Corp.

Reisner, M. 1986. Cadillac Desert: The American West and its Disappearing Water. New York: Viking.

Riese, W. C., Pelzmann, W. L., \& G.T. Snyder. 2005. "New insights on the hydrocarbon system of the Fruitland Formation coal beds, northern San Juan Basin, Colorado and New Mexico, USA." Coal Systems Analysis, 387, 73.

San Juan Public Lands Center. 2006. Final Environmental Impact Statement: Northern San Juan Coal Bed Methane Project. Durango, CO: San Juan Public Lands Center (combined Bureau of Land Management and US Forest Service office).

Sarewitz, D. 2004. "How science makes environmental controversies worse." Environmental Science \& Policy, 7(5), 385-403.

Schackley, S. 2001. "Epistemic Lifestyles in Climate Change Modeling." In Changing the Atmosphere: Expert Knowledge and Environmental Governance, edited by C. Miller and P. Edwards. 107-134. Cambridge: MIT Press.

Schlager, E. 2006. "Challenges of governing groundwater in the U.S. western states." Hydrogeology Journal, 14: 350-360.

Snyder, G. T., \& J.T. Fabryka-Martin. 2007. "I-129 and Cl-36 in dilute hydrocarbon waters: Marine-cosmogenic, in situ, and anthropogenic sources." Applied Geochemistry, 22(3), 692714.

Stegner, W. 1954. Beyond the Hundredth Meridian: John Wesley Powell and the Second Opening of the American West. Boston: Houghton Mifflin.

Tidwell, V. C., \& van den Brink, C. 2008. "Cooperative modeling: linking science, communication, 
and ground water planning." Ground Water, 46(2), 174-182.

U.S. Government Printing Office. 1891. "Sundry Civil Appropriation Bill: Statement of Maj. J.W. Powell, Director of the Geological Survey, June 4, 1890." Reports of Committees of the House of Representatives for the First Session of the Fifty-First Congress. Washington, D.C.: U.S. Government Printing Office.

U.S. National Academy of Science (NAS). 2010. Management Effects of Coalbed Methane Produced Water in the Western United States. Washington, DC: National Academies Press. Retrieved: http: / / www.nap.edu/catalog/12915.html

Vance v. Wolfe. 2009. Colorado Supreme Court Case No. 07SA293, April 20, 2009.

Williams, M., Kroepsch, A., Nydick, K., Gianniny, G., Vansickle, J., Peltz, C. 2010. Isotopic and Geochemical Analysis of Groundwater-Surface Water Interactions at the Fruitland Outcrop: An Addition to the $4 M$ Project. For the San Juan Public Lands Center, Durango, CO.

Wijnen, M., Augeard, B., Hiller, B., Wrad, C., \& P. Huntjens. 2012. Managing the Invisible: Understanding and Improving Groundwater Governance. World Bank. http:/ / water.worldbank.org/sites/ water.worldbank.org/files/publication/ESW_Managi ng-the-invisible.pdf

Zhou, Z. \& C. Ballentine. 2006. "He dating of groundwater associated with hydrocarbon reservoirs." Chemical Geology, 226: 309-327. 